Finanse, Rynki Finansowe, Ubezpieczenia nr 4/2016 (82), cz. 2

\title{
Value Co-creation in the Popular Music Industry
}

\author{
Wlodzimierz Rudny"
}

\begin{abstract}
Summary: Purpose - The aim of this article is to analyze how organizations operating in creative industries can transform their business model to remain competitive and to preserve their profitability. Research methodology-The study is based on literature overview.

Result-In the popular music industry a shift has taken place from value creation to value co-creation, which is fundamentally changing the relationship between consumers and producers. Rather than being passive recipients of products and services, consumers now form part of a diverse network of actors co-creating value. Originality/value- The article provides the analysis of the music industry from the perspective of value cocreation
\end{abstract}

Keywords: value co-creation; business models; music industry

\section{Introduction}

Over the past twenty years, the emergence of the Internet and digital technologies significantly reduced physical constraints and facilitated the distribution of music, videos, software, and information. Consumers can therefore easily access a vast array of creative content available in the digital world. Even if such changes provide great opportunities from the consumer's point of view, they represent a major concern for creative industries involved primarily in the generation and exploitation of creative contents. In this context, the evolution of creative industries requires innovation in two main areas. First, legal institutions have to design new frameworks to preserve intellectual property rights. Second, organizations involved in creative industries have to rethink their business models to remain profitable and competitive in changing environments

\section{Value co-creation - theoretical foundations}

The creation of value is the core purpose and central process of economic exchange. The nature of value has been discussed since Aristotle who first distinguished between "use value" and "exchange value". Two different meanings of value, "value-in exchange" and "value-inuse", reflect different ways of thinking about value and value creation.

\footnotetext{
* dr hab. Włodzimierz Rudny, Uniwersytet Ekonomiczny w Katowicach, Katedra Zarządzania Przedsiębiorstwem, e-mail: rudnyw@ue.katowice.pl.
} 
A traditional view is referred to as goods-dominant (G-D) logic and is based on the value-in-exchange meaning of value (Vargo, Lusch, 2004). In G-D logic, value is created (manufactured) by the firm and distributed in the market. The role of "producers" and "consumers" are distinct. Value creation is understood as a series of activities performed by the firm.

Over time, a different perspective has evolved. Rather than seeking to put protective barriers between themselves and their consumers, competitors and suppliers, firms started to seek and cultivate social knowledge and involve diverse actors in the value creation process (Sawhney et al., 2005). A notable example is Microsoft, which in the 1990s began releasing beta versions of its software for its customers to test, debug and improve. Another example of co-creation in the computer industry is the open-source software movement. This is where users have full access to the source code and can make their own changes to a program to meet their personal needs.

This shift in the paradigm of value creation has been given a variety of names, such as 'co-creation experience', 'open innovation', 'wikinomics'. However, most frequently it is referred to as 'service dominant (S-D) logic'(Vargo, Lush, 2004).

S-D logic is linked to the value-in-use meaning of value (Vargo, Lush, 2008). Service is defined as the application of competencies (knowledge and skills) by one entity for the benefit of another (Vargo, Lusch, 2004). A service system is defined as a configuration of resources connected to other systems by value propositions. In S-D systems the roles of producers and consumers are not distinct. The value is co-created in interactions between the firm and the consumers. The competencies of both are integrated.

The S-D logic view of exchange challenges the foundations of economics. In the G-D logic view, the purpose of economic exchange is to make and distribute things to be sold. The S-D view is that all exchange is based on service. Goods are service delivery vehicles. In S-D logic, knowledge and skills are the key resources for having a competitive advantage. The essence of the contrast between S-D and G-D logic lies in the basis of exchange. The first one focuses on the action of operant resources (i.e. those that upon other resources), such as knowledge and skills, whereas G-D logic focuses on the exchange of operand resources (those that result from operations performed on them, such as goods (Vargo, Lusch, 2004). For S-D logic value results from the beneficial application of operant resources and is co-created through the combined efforts of firms, employees, customers, and other entities related to the exchange. When value creation is seen from a service systems perspective, the producer-consumer distinction disappears and all participants contribute to the value creation for themselves and for others. Moving the locus of value creation form exchange to use means transforming the understanding of value from one based on units of firm output to one based on processes that integrate resources.

Value co-creation has been greatly enhanced by the rise of the Internet and convergence of industries and technologies that is shifting the traditional boundaries of products and services As a consequence, customers' knowledge and skills can become a valuable resource 
for firms, allowing them to gain the flexibility needed to adapt to the rapidly-changing business environment.

\section{The business model approach}

Although the concept of the business model is considered useful, there is lack of consensus on what comprises a business model. Business model definitions build on traditions of business strategy and try to combine different views on strategy and performance from a different perspective, the term business model is often used for describing the underlying logic for supplier's revenue and profit generation. Under the S-D perspective, a business model addresses both value creation for the customer and value capture for the supplier.

Based on the literature, one can identify six elements of a business model: (1) customer, (2) value proposition for the customer, (3) competitive strategy, (4) position in the network, (5) suppliers' internal organization and its key capabilities and (6) logic of revenue generation (Kujala et al., 2009). According to Demil and Lecocq (2010), the business model may be understood as the description of the way an organization operates to ensure its sustainability. Thus, in the most basic sense the business model provides information of how a company is organized to make money in an industry.

The business model concept has been developing due to the need for new ventures in the Internet industry to explain to investors how they can generate value from technology. A useful tool for analyzing business models is provided by the RCOV framework (Demil, Lecocq, 2010). The basic assumption of the RCOV model is that a firm builds its business model by answering several questions: how to leverage resources and competencies (RC), what the internal and external organization of the business is (organization) and how to supply products and services to markets (value propositions). Organization $(\mathrm{O})$ refers to the choice of operations that an organization performs (its value chain) and to the relations it establishes with external stakeholders (its value network, including suppliers, competitors, regulators, and complementors) to exploit its resources and competencies. Value propositions $(\mathrm{V})$ are delivered to customers in the form of products and services. Firms may address value propositions to various kinds of "customers" (end consumers, suppliers, competitors, government, etc.), particularly in the case of multi-sided markets. Value propositions encompass three aspects: what will be proposed (products and services), how it or they will be proposed (access terms), and to "whom" (customers).

Researchers have identified value co-creation activities in many areas of business; however, one area which appears to have been neglected is the cultural sector (e.g. TV, radio, film, theatre, books, advertisements and popular music). Cultural industries are distinct in that they produce mainly symbolic goods - goods, such as books and paintings, whose value arises from their ability to bring forth an emotional response from consumers (O'Connor, 2000). Value co-creation in these industries arises less from producing tangible benefits for consumers and more from increasing emotional value. 


\section{The music industry and value co-creation}

The popular music industry has been dominated by a few major record labels since the end of the nineteenth century. However, while the major labels were very profitable in the 1960s and 1970s, in recent years they have found it much more difficult to make money, with sales falling and rising losses (Jones, 2012). Though classed as a cultural industry, big music companies used to operate in the same manner as other big businesses, using methods such as portfolio analysis to identify 'cash cows' (rock music) and 'dogs' (world music). Adorno (1990) argued that the major labels have commoditized music to the extent that music production resembled the assembly-line production of standardized products. The aim was not musical excellence, but profit maximization.

The record industry's value proposition used to be quite simple. The industry was about selling records, and there were no other revenue sources. In addition to having a single product (records) and a single revenue source (music consumers), the marketing was also very standardized. The traditional business model was composed of several activities. The role of artists, which includes musicians and composers, was to create and perform music. Then labels transformed artistic creation into a marketable product. Most key resources and competencies of the record industry's traditional business model were directly related to creativity. The ownership of masters was a fundamental resource because it greatly determined the record companies' capability to create value and to make profit.

Value co-creation has been greatly enhanced by the rise of the internet and its associated interactive media forms. Co-creation requires direct interaction between producers and consumers. In the music industry, this has been limited by the absence of an enabling technology which would allow fans to surmount obstacles of time and space (Jones, 2002). The advent of the Internet, especially Web 2.0, has offered the potential to overcome these obstacles and open up opportunities for value co-creation. The internet offers new opportunities and challenges to the music industry's traditional business and management practices, particularly in terms of digital distribution, changing consumer behaviour and intellectual property management

After the introduction of the Internet and MP3 technology, the record industry was faced with new opportunities and threats due to the evolution of its environment and its competitive structure. In order to take advantage of these opportunities, the record industry decided to reorganize its value network. However, the emergence of digital channels had a negative impact on record sales, which rapidly decreased after 2002. As a consequence the record industry had to rethink its business model to remain profitable. The purpose was not to significantly transform the business model but to reinforce the traditional value-creation logic in order to make more profits. This required access to a combination of specific resources and competencies (infrastructures, skills related to web development, and technology management). For this reason, the major labels bought several e-business start-ups (MP3.com was taken over by Universal Music for $\$ 372$ million, while Bertelsmann bought Napster for 
$\$ 85$ million). Through these big investments, major labels were able to achieve full vertical integration.

Despite these efforts, the major digital music platforms failed to attract music consumers. The digital market did not grow as expected and the adopted strategies appeared to be unsuccessful. Starting in 2006, the record industry adopted completely different approaches to make more substantial changes to its business model. The record labels tried to take advantage of opportunities that were arising in other industries and developed innovative partnerships with companies operating in the fields of electronics (Apple and Dell) and telecommunications (Orange and Vodaphone) and on the Web (Google and YouTube).

Using the business model approach, one can identify three different models that record labels started to implement since that time: extending value networks, bundling value propositions, and validating new resources and competencies (Moyon, Lecocq, 2015). The innovative partnerships were based on complementarities between the record industry's value proposition and that of outsiders. A value proposition is complementary to another when it has a positive impact on consumers' willingness-to-pay. For instance, consumers' willingness to pay for a digital portable device is much higher when they have access to music content. Based on complementarities, the record industry developed innovative partnerships outside its boundaries.

\subsection{Extending value networks}

The partnership with Apple was one of the first to be established outside of the record industry's boundaries. After the success of the iPod, Apple established a digital retail platform (iTunes) to sell music online. Hence the mobile phone market was rapidly growing, partnerships with telecommunication providers (Vodaphone and Orange) also offered the record industry the ability to create new streams of income. Several deals were also signed with ISPs (e.g., AOL, MSN, and Yahoo) to use their platforms to offer on-demand music

\subsection{Bundling value propositions}

Starting in 2006, the record industry adopted a different approach toward outsiders. Partnerships more frequently led to a "bundled" value proposition that enabled the record industry to capture some of the revenue resulting from the sales of complementary products or services. For instance, partnerships between record labels and electronics manufacturers were established (e.g., Sony Music and Packard Bell, and Warner Music and Samsung). This helped to capture revenue from the sales of electronic products. Also, the record industry established multiple partnerships with content providers on the Internet in order to share their revenue (YouTube and Spotify). 


\subsection{Validating new resources and competencies}

From 2007 on, the record industry, and more specifically the major labels, implemented "360-degree" strategies to capture revenue from every activity in which artists participated. New resources and competencies were required to develop these 360-degree activities. The first step was to extend the scope of the artistic contracts. While contracts traditionally concerned only the production of a master, major labels introduced new types of contracts that covered the artists' live performances and image.

The second step was to acquire competencies that the major labels did not have. To do so, they chose to integrate companies endowed with such capabilities (touring companies, merchandising companies, and even concert halls).With the development of these new activities, the paradigm in the record industry has shifted from a record-oriented business to an artistoriented one. Labels developed a wide range of services for the artists, which resulted in the diversification of revenue sources.

\section{Conclusions}

As a consequence of technological progress and, in particular, the development of Internet organizations operating in creative industries had to transform their business models to remain competitive and to preserve their profitability. The shift has taken place from value creation to value co-creation, which is fundamentally changing the relationship between consumers and producers. Rather than being passive recipients of products and services, consumers now form part of a diverse network of actors co-creating value. In the music industry the role of fans has radically changed, i.e., from undermining the industry through piracy they are increasingly enhancing and co-creating value in partnership with artists and small record labels.

The internet is enabling fans, artists and smaller record labels to change established, standardized approaches to music production and consumption.

\section{References}

Chaney D. (2012). The music industry in digital age. International Journal of Arts Management, 15 (1), $42-52$.

Choi H., Burnes B. (2013). The internet and value co-creation: the case of popular music industry. Prometheus, 31 (1), 35-53.

Demil B., Lecocq X. (2010). Business model evolution: In search of dynamic consistency. Long Range Planning, $43(2-3), 227-246$.

Jones S. (2002). Music that moves: popular music, distribution and network technologies. Cultural Studies, 16 (2), 213-232.

Chaney D. (2012). The music industry in digital age. International Journal of Arts Management, 15 (1), 42-52.

Kujala S., Artto K., Aaltonen P., Turkulainen V. (2010). Business models in project-based firms - Towards a typology of solution-specific business models. International Journal of Project Management, 28, 96-106.

Lusch R., Webster F. (2011). A stakeholder-unifying, co-creation philosophy for marketing. Journal of Macromarketing, 31 (2), 129-134. 
Moyon E., Lecocq (2015). Rethinking business models in creative industries. International Studies of Management and Organization, 4, Winter 2014-15, 83-101.

Sawhney M., Verona G., Prandelli E. (2005). Collaborating to create: the internet as a platform for customer engagement in product innovation. Journal of Interactive Marketing, 19 (4), 4-17.

Vargo, S., Lusch R. (2004). Evolving to a new dominant logic for marketing. Journal of Marketing, 68 (1), 1-17.

Vargo S., Lusch R. (2008). Service-dominant logic: continuing the evolution. Journal of the Academy of Marketing Science, 36 (1), 1-10.

Vargo S., Maglio P., Akaka M. (2008). On value and value co-creation: A service systems and service logic perspective. European Management Journal, 26, 145-152.

\section{WAPÓŁTWORZENIE WARTOŚCI NA PRZYKŁADZIE PRZEMYSŁU MUZYCZNEGO}

Streszczenie: $\mathrm{Cel}$ - Celem artykułu jest analiza ewolucji modelu biznesowego organizacji w przemysłach kreatywnych, w celu podtrzymania konkurencyjności i rentowności.

Metodologia badania - Artykuł został przygotowany w oparciu o studia literaturowe

Wynik - W przemyśle muzycznym widoczna jest zmiana modeli biznesowych zmieniająca w sposób fundamentalny relacje pomiędzy producentami a odbiorcami muzyki. Istotą tej zmiany jest coraz bardziej powszechne współtworzenie wartości.

Oryginalność/wartość - Artykuł eksponuje problematykę procesów współtworzenia wartości w przemyśle muzycznym, rzadko będącym przedmiotem analizy w kontekście wartości rozumianej jako kategoria ekonomiczna (a nie wyłącznie emocjonalno-symboliczna).

Słowa kluczowe: współtworzenie wartości; modele biznesowe; przemysł muzyczny

\section{Cytowanie}

Rudny W. (2016). Value co-creation in the popular music industry. Finanse, Rynki Finansowe, Ubezpieczenia, 4 (82/2), 463-469. DOI: 10.18276/frfu.2016.4.82/2-40. 